VS-I-1 肝門部胆管短に対する肝十二指腸間膜切

除術一解剖学的特性から肝動脈再建を要しない間膜切除 兼尾状葉合併右三区域肝切除術

香川医科大学第一外科

○岡田節雄、高間雄大、森 諴治、淒本 项、

若林久男、前場隆志、前田 堅

肝十二指腸間膜切除兼尾状菜合併拡大訮菜切除 (rHL) は肝門部胆管癌に対する根治性を高める点において重要 であるが、動脈再建に伴う合併症はときに致命的である。 この点を考虑し、解剖学的特性（左肝動脈分岐異常）か ら肝動脈再建を必要としないrHLを 3 例経験したので、 うち 1 例を供筧する。[症例］57歳、男性。肝門部胆 管灙で左胆管のみPTBDを施行し、門脈右枝のPTPEによ り肝外側区体積の11\%增加を誘蕃後に根治術を施行した。

[手術手技のポイント] 本例では温存する左胃動脈分 岐型左肝動脈が小網内を走行するため、主に右側から尾 状葉を剥離した。動脈はCHAで切蜼、胆管はB2,B3別々 に切離しen blocにrHLを施行した。門脈再建は直接端々 吻合が可能であった。[結語]肝門部胆管疾の手術の 問題点として肝側断端追及切除の困難性、術中肝虚血、 再建動脈の開存性が挙げられるが、本法ではこれらの点 を解決する普遍的術式に成り得るものと考えられる。

VS-I-2 肘門部胆管稫に対する手街術式の問题 点と工夫

球大学医学部第 1 外科 “，国立長崎中央病院外科 ${ }^{21}$ 白石祐之 "，草野敏臣，玉井逢，宮里 浩， 伊佐 勉, 武藤良弘, 古川正人 ${ }^{21}$

[目的］肝門部胆管癌（本症）に対する手術成綪を䔔 隔切除成績より検討し、血管合併切除例における血行 再建の工夫について報告する。

[対象・方法] 本症82例中, 切除された52例を対象と し、衍式別の手術成嘖からretrospectiveに検討した。 [成结] 本应切除52例の術式は、肝外胆管切除および 肝門部切除37例、肝外胆管切除および肝葉切除17例で あった。应大肝葉切除併施例は 5 年生存 6 例之良好で あったが、術後肝不全による在院死 3 例を経唭した。 一方、最近肝機能不良例に施行している肝右葉を温存 し、肝門部脈管、星状葉合併切除後、血行再建した症 到は、治范切除率、生存率で良好な成紿を示した。

[対策と工夫] 1. 根治性を向上させる目的で、可能で あれば拉大肝右葉切除を施行する。肝機能不良例は、

肝葉を温存した術式を選択し、症例によっては肝門部 脈管を切除し再建する。2.門脈再建は自家静脈を使用 し、肝動脈再建は胃大絧動脈や中結腸動脈などで血行 路変更を行う。以上、手術手技を映像で紹介する。

\section{VS-I-3 血行再建を伴う訮門部胆管富の手術}

山形大学第 1 外科

○石山秀一, 布施明, 久津裕，川口清，塚本 長

【目的】我々の行っている血行再建について報告し血 行再建を伴う肝門部胆管癌手術の問題点を検討する.

【対象・成績】対象：肝門部胆管畐肝切除 43例。こ のうち血行再建を10例（動脈 3,門脈8）に併施。動 脈は全例切除吻合，門脈は切除吻合 4 , 形成 2 , 大伏 在静脈バッチ1，外腸骨静脈グラフト1例。入院死亡 率は再建例 40 ，非再建例 $12 \%$ で再建例の死因は肝脑 瘄, 腹腔内出血, 肝不全, GVHD. 入院死を含む1年， 5 年生存率は再建例：60，36\%，非再建例：78，36\%。

【考察】再建例の入院死亡率が高いが遠隔成續は同等 で血行再建は切除率, 遠隔成績向上に寄与し得ると考 えられるが，周術期成績の向上が必要である，入院死 亡に感染の関与が大きく血行再建例では特に腹腔内感 染から肝腈倡や出血をきたし易い. 確実で開存生の高 い血管吻合と吻合部の感染からの保護が重要である.

【ビテオ】大伏在静脈バッチおよび外腸骨静脈グラフ トを用いた門脈再建, 影微鏡下の動脈再建の手技を示 す.成績向上の工夫として吻合部は fibrin glue によ り被動脈吻合は顥微鏡下で行う，HPDでは腈胃 吻合を採用，胆管と膵の吻合部を分雕する.

VS-I-4 血行再建を伴5肝門部胆笶窝の手術 における問題点と工夫

\section{慶應義檠大学外科}

島津元秀, 若林 剬, 加藤修太郎, 板野 理, 上田政和，高橋 伸，北島政樹

肝門部胆等䆗 51 例に対し肝切除を伴う根治的切除を 行った. その5ち 11 例に門脈およひ肝動脈（両者： 2 例, 門脈: 8 例, 肝動脈: 1 例) の切除・再建を行 った. 全体の 5 年生存率は $20 \%$, 在院死亡は 2 例で， 血行再建例はそれぞれ $25 \%$ ，0例であり，両者に差 はなかった. 再建方法は, 門脈が端端伆合 7例, 維合 2 例, Gore-Texグラフト 1 例で, 肝功脈は端端吻合, 右胃大網動脈翻転，自家静脈グラフト，各 1 例であっ た. 肝門部血管再建の問題点としては，1）吻合血篔 に口径差あるいは走行角度の差がある，2）視野が深 く，また鉗子のゆとりが少ないため吻合が嚾しい， 3) 門脈再建では残存肝が偏位して, 屈曲・ねじれを 生じやすい，4）肝動脈再建では肝側の口经が細く, 閉塞をきたしやすい，などが挙げられる. 対策として は，1）吻合部を斜めに切離する，割をいれる，2） intraluminal method で吻合する，3) 残存肝を固 定する，4）ルーペまたは顕微鏡を用いる，などであ る.これらの工夫をビデオにて供臨する. 
VS-I-5 門脈合併切除を伴う定型的肝左栗切除術 獨協医科大学第 2 外科

大盛芳路、小重洋暉、伊藤生二、佐久間敦、根本强彦、 楆上索

【目的】肝門部胆管盘に対する定型的肝左蕃切除で、 左右門脈分岐部を切除した症例を供覽し、その畅合法、 growth factor の必要性について言及する。

【症例】60歳男性。全身倦总感、黄㾝を主訴に紹介入 院した。入院時検查所見では、AST 103 IU/, ALT 169 $\mathrm{IU} /$, total bilinubin $13.7 \mathrm{mg} / \mathrm{dl}$ ( direct bilirubin $10.9 \mathrm{mg} / \mathrm{dl}$ ), Al-P 867 IU/, LDH 382 IU/, $r$ GTP 300 IU/, CEA 13.7 $\mathrm{ng} / \mathrm{ml}$ ，CA19-9 60U/mlであった。入院当日にPTCDを 施行し、左肝管を主座とし、右肝管、上部胆管、肝内 胆管に浸澗する胆管癌上診断した。减黄後、左側尾状 集を合併切除する定型的な旰左葉切除術を施行した。 肝動脈には息の浸潤はなかったが、門脈に直接浸潤を 認めたため、門脈の左右分岐部を合併切除した。門脈 は一点支持で吻合したが、 growth factorは贯かなかっ た。門脈遮断時間は 9 分であった。

【考残】門脈の吻合では growth factor の必要性が強調 されてきたが、growth factorは必ずしも必要ではない ことが示された。肝門部胆管盘て血管沒潤を有する症 例では、搜楅的に合併切除をすへきである。

VS-I-6 “広義” の肝門部胆管癌切除における 門眽再建の問題点と工夫 山口大学第二外科

○西田峰勝, 前田義隆, 高尾康一郎, 高尾貫史, 原田 菊夫、衛簿隆一、岡 正朗

肝内胆管 2 次分岐を中心に発生した胆管癌は敞密に言 う之胆管細胞癌であるが、その進展様式は通常の肝門 部胆管癌と同様であり、我々は”広義”の肝門部胆管 癌として取り报っている。しかし、“広義”の肝門部 胆管癌は、症状（黄疸等）がでるまでの期間が長いた めか血管浸潤などの割合が高く、ほとんどの症例で血 行再建が必要となってくる。この嘹、末梢側の門脈は、 肝内で切離せざる得ず、吻合が困難となることが多い。 このため我々は、肝切離を先行させ残存予定肝区域の グリソン鞘を露出し、これを剥離し末梢側門眽を露出 するようにしている。また、門脈再建は、後壁を intraluminal methodのvertical mattressにて、前壁を通常 のvertical mattressにて外䐓縫合にて行っている。传壁 維合に際して門脈を反転させると支持系周囲に壁の弛 みが生じ、確実なvertical mattress繾合ができないこと があり、我々は、門脈の反転が可能な症例に対しても intraluminal methodのvertical mattressを基本にしている。 最近我々は、3 例の門脈再建を必要とした”広義”の 肝門部胆管朢を経験したので、門脈再建を中心にビデ オにて供臨する。
VS-I-7 肝門部胆管癌に対する肝門部門脈合併切 除、再建一パッチ再建と端々吻合直接繾合再建の比較 埼玉医科大学釉合医㞠センター外科

○高浜龍彦、金井福栄、大西 清、鈴木 毅、 黾谷雄一郎、中田 博

門脈浸潤を伴う肝門部胆管癌に対し、私共は尾状菜 全切除を伴う肝三区域切除に、肝門部門脈合併切除、 自家静脈パッチまたは直接栈合端々吻合による血行再 建を施行している。

【症例 1】51才男性。肝門部にて左右胆管の交通な く、門脈左枝完全閉塞あり。尾状葉をふくむ左三区域 切除、肝門部門脈合併切除、自家静脈パッチによる門 脈再建を施行し、肝動脈は非再建とした。【症例 2】 77才男性。肝門部胆管癌で左右の交通なく、尾状葉切 除、右三区域切除、肝門部門脈合併切除、自家静脈パ ッチによる血行再建を施行、左肝動脈は温存した。

【症例 3】65才男性。胆裳癌、肝門部胆管浸潤で門脈 左枝が分岐部の末梢側で1/3腫瘍よ浸閏あり。尾状葉を 含む右三区域切除に門脈左枝 $1.5 \mathrm{~cm}$ 合併切除、端々 吻合直接圱合再建にて血行再建した。【考按】パッチ 再建した2例は術後順調に経過したが、直接释合再建 した症例 3 は術後門脈血栓にて失った。パッチ再建の 方が有利と考えており症例 2 の手枝を供覧する。

VS-I-8 門脈浸潤を呈した肝門部胆管癌に対す る門脈合併切除を伴う拡大訮右葉+尾状葉切除

東京大学第二外科

○隺田敬一、幕内雅敏、高山忠利

門脈浸潤を伴った肝門部胆管癌に対する払大肝右葉切 除+門脈合併切除の手術手技を供覧する。症例は 63 歳、 男性。心䆚部痡、黄㾝を主訴に来院。諸検査により右 肝管への浸潤有意の肝門部胆管鸨と彭断さ九、腹部血 管造影で門脈左右分岐部への癌浸濶が示唆された。開 腹時、右葉は門脈右枝狭狂のため萎縮していた。まず、 門脈梳部で S4inf, S1 に向かう脈管を処理し、左枝に テーピングできることを確認した。左肝動脈から固有 肝動脈に治い部清し、右肝動脈は根部で切噰。変色域 が明瞭になり後の肝切離線とした。さらに8．7．9(右 側)、13 番リンパ節を郭清した後、総胆管を切傩し(断 端癌陰性）、門脈を露出するように癌浸潤部手前まて 郭清した。肝右葉授動後、S4inf を含む払大肝右葉+尾 状葉切除を施行。門脈本幹と左枝にブルドッグ錐子を かけ癌浸潤部門脈を合併切除し、最後に門脈膀部右側 で胆管を切離し en-blocに切除した。胆管空晹吻合し 手術终了。病理所見は ss, ly0, v2, pn3, hinf2, vs2(Vp), n(-), 3(-), hw0, ew0, stage IV であった。術後 7 ヶ月経 過した現在再発徵候なく、順調に経過している。 
VS-1-9門脈浸型を伴う肝門部胆管癌に対寸る 肝右葉+尾状葉切除:門脈切除再建を先行する肝切除術 名古屋大学医学部第一外科

○难野正人、一村雄次、神谷顺一、金井道夫、上坂克彦

【緒尚】肝切灕前に門脈切除再建を先行して行う術式 をビデオで供覧ずる【症例】65歳、女性。黄痽にて 発症し、計 5 本の PTBD カテーテルによる减黄後に手 術を施行した。【手術】総胆管を切雕し、肔十二指腸 間膜の skeletonization resection 八と進める。右肝動脈を結柋切雕し、門脈本幹にテー ブをかける。左門脈臍部(UP)前面の墏膜を開き UP を 露出した後、そこから逆行性に左門脈横行部を露出し、 これにテープをかける。数本の尾状藮門脈枝を結督切 離する。血管銝子を門脈本幹および左門脈横行部にか け、門脈を切傩する。吻合には 5-0 プロリンを用い、 一点支持連続䋖合で端々伆合を行う。次いで、右葉を 脱転しつつ、短肝静脈および右肝静脈を切雕する。 Cantlie 楾に沿って肝切雄を行う。中肝静脈沬残すが、 その右側背側を露出し、肝切推を Arantius 管に方向人 と進める。左肝管をUP の右側で切離し、石葉、尾状 莱、肝外胆管、門脈を en bloc に切除する。【結語】右 からの肝切除では多くの場合、門脈切除再建を先行す る術式が可能である。

VS-I-10 肝門部胆管癌に対する左三区域+尾状葉 切除、門脈+右肝動脈切除再建術の問題点と工夫

横兵市立大学第2外科

○遠藤 格、瀧本 篤、多井秀宣、高橋徹也、

国広 理、関戸 估、渡会伸治、仲野明、嶋田 紘、

進行肝門部胆管癌に対する血管合併切除再建の成功率 は向上したか、その問題点の解決と手術成績の評価は未 だ確定していない。【対象】尾状葉を含む肝区域切除を 施行した肝門部胆管癌20例中6例に血行再建(門脈+動脈=5 例, 門脈=1例)を行った。門脈+肝動脈は全例左からの切除 (左葉+尾状葉 $=3$, 左三区域十尾状葉=2)に行った。【結果】 剥離面癌浸閵(ew) はew $0=2$, ew $1=4$, ew $2=0$ 例 とすることが できた。しかし門脈血栓 1 、胆腸吻合綘合不全 $1 、$ 阶膿瘍 1 例の合併应を経驗した。最長4年9力月生存中であり延命効 果があると考えられた。【問題点解決の工夫】安全性確 立の対策として、教室の予後得点に基づき苽前門脈塞栓 術を施行し残肝volume\%か330\%以上となれば抬大切除を 施行している。残肝の阻血時間を可及的に短くするため 門脈再建は動脈血流を保ちつつ行う。中・左肝静脈の切 離は肝切離の最後に行い切除肝の血による出血を少な くする。門脈吻合は狭篮、捻九に注意し、動脈吻合は頙 微短下に行っている。ビデオでは以上の点に留意し左三 区域+尾状葉切除、右肝動脈切除再建を行った一例を示す。
VS-I-11 肝門部胆管窝切除時の門脈および肝動

脈再建の工夫

千葉大学医学部第一外科

○宮崎勝、伊藤 博、中川宏治、安蒜 聡、清水宏明、 清水善明、尾本秀之、加藤 厚、中村俊太、奥野厚志、 野沢聡志、貫井㭲次、中島伸之

肝門部胆管灂はしばしば門脈・肝動脈へ浸潣を認め る為、その切除に際し脈管合併切除が必要となる。我々 は 1997 年 3 月までに 88 例の切除を行ない、24 例（27 \%) に門脈切除再建、8例 (9\%) に肝彭脈切除、内 6 例に動脈再建を併施した。門脈再建の 24 例中端々吻合 し得たのが 21 例 $(87 \%) て ゙ 3$ 例（13\%) に自家静脈 グラフトを要した。用いたグラフトは内腸骨静脈 1 例、 左鳌静脈 2 例でった。肝動脈合併切除 8 例中再建 6 例 は、右肝動脈再建 4 例、左肝動脈再建 1 例、右後区域枝 動脈 1 例でおった。肝動脈再建は胃十二指腸動脈を切離 して固有肝動脈を举上させる方法と胃十二指腸動脈を 長く牫し切離し翻転させ、残肝動脈と吻合する方法を 用い、グラフト使用例はない。肝門部胆管癌における 脈管合併切除再建例の予後は非合併切除例に対し不良 であるが、術死在院死率に差異はなく予後向上にはさ らなる工夫が必要と思われる。

\section{VS-I-12}

肝門部胆管癌の肝動脈・門脈再建におけ

る工夫

徳島大学第 1 外科 ○福田洋、田代征記、余喜多史郎、池 山鎮夫、井川浩一、岡真由美、佐々木克也、宮内隆、八木恵子、 安蒌勤、石川正志、三宅秀則、原田雅光、松村敏信

【目的】血行再建を伴う肝門部胆管癌において動脈再建 の方法や門脈の血管径の不同はよく問題となる。今回血 行再建の 3 例をビデオで供臨する【症例 1】48 衤、男。 占拋部位は $\mathrm{Bl}$ で拡大左葉切除施行。右肝動脈に浸潤を認 め切除し左肝動脈を再建に用いた。血管径は約 $2.5 \mathrm{~mm}$ で 口径差なく 7-0 prolene $の 1$ 点支持で連䊦縫合. growth factor を的 $3 \mathrm{~mm}$ 置いた。遮断時間は 39 分。術後の血管造 影で開存は良好。【症例 2】71歳、女。術前に門脈本幹 の硬化像 $(+)$ 。 Brls で右門脈塞栓後 54 上部温存拡大肝右 葉切除施行。門脈本幹から左門脈にかけて漫潤を認め $3 \mathrm{~cm}$ の門脈を切除。再建は端端で 5-も prolene を用い後壁は intraluminal method, 前壁は over \& over の連続链合 を行い growth factor を直径分置いた。遮断時間は 15 分。【症例 3】61 祘、女。BsrmC で右門脈塞栓術後 S4 上部昷存拡大肝右葉切除施行。門脈本幹から左門脈にか けて漫潤を認め $2 \mathrm{~cm}$ の門脈を切除。再建は症例 2 と同样 であるが口径差を認め肝側の門脈左枝は斜めに切離した。 吻合後も捻れや狭窄はなかった。遮断時間は18分。

【まとめ】1. 右肝動脈再建に左肝動脈を用い口径差や婜 張はなく有用であった。2.肝門部の門脈切除においては 口径不同か問題となるが症例に応じたさが必要である。 


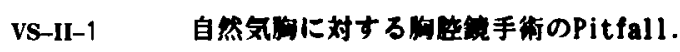
トヨ夕記念病院呼吸器外科

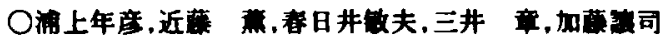

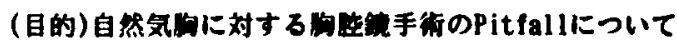

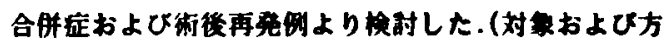
法)1991年10月以降当科において自然気㘬に対し施行し

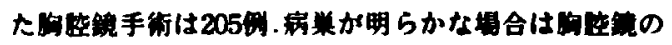

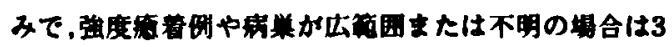

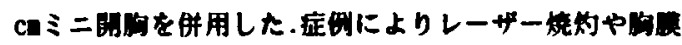

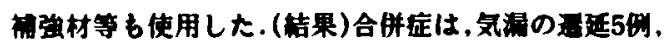

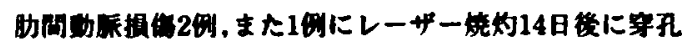

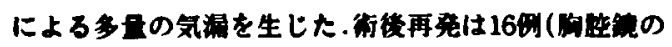

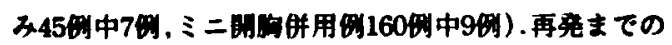
期间は1-36力月(平均15.2力月).再手術13国の检討で原

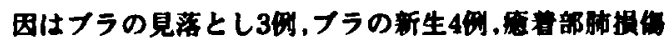

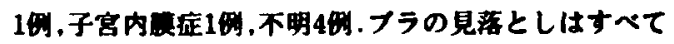

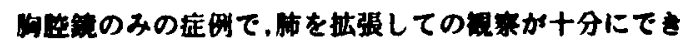
なかったためと思われた。フラの新生は切回手街

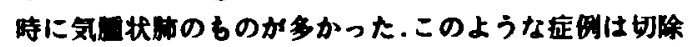

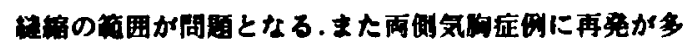

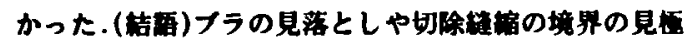
めの甘さか同手行のPitfallとなっており、我々は街良

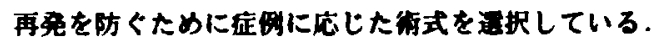

VS-II-2 胸肤鏡下手術におけるpitfal1-瘾着と 出血 - とその対策

国立札幌病院・北海道がんセンター外科

○近藤啓史、佐々木迪郎、内藤春彦、高售宏明、有倉 潤、高岡正実

「缁着と出血」は胸腔鏡下手術のpitfallとしては 日常的な可能性を持ち、その対策としての剥離・切離 と止血は開胸を避ける為にも重要である。今回我々は これらのpitfall の対策とそのための手術器具の工夫 を中心に報告する。

「瘭着」は肺一胸壁、肺一肺門などにあ、これらの 剥離操作は通常胸胿鏡用鉗子・跠と吊り上げ式腹腔鏡 用の通電可能な鋏を使用している。軽度の瘜着剥離に はツッペル、成毛式コットンフィンガー、茵ブラシな どを使用している。肺全体に及ぶ虑着の場合はその距 離約 $7 \mathrm{~cm}$ の穴を 2 固開け、両示指でその間を剥離し器 具を使用できるようにしている。「出血」は止血困雜 な場合は開胸に至るため、その対策とその見椣めは非 常に重要である。止血は小血管では電気凝固が基本と なる。胁間動脈より太い血管の損傷では糸による結 紮、血管クリッブを使用している。肺損侮による出血 には最近開発したワンハンド式直針腱合器具マニセブ スを使用した梿合結紮による止血を基本としている。
vS-II-3 胸部食道癌に対する镜視下切除の問題点

大阪市立総合医療センター消化器外科、大阪市立大 学第 2 外科*

○東野正幸、大杉治司*、德原太豪*、木下博明*

「目的と対象」我々は胸部食道癌に対して通常開胸と 同等のリンパ節垶清を镜梘下でも行うことが可能であ るとの考えのもとに胸部食道癌 32 例に対して手術を 行ってきた。これらを対象に鏡視下手術の問題点と工 夫について検討する。「工夫と結果」通常開胸手術と 同等のリンパ節郭清を行うために約 $5 \mathrm{~cm} の$ mini 開胸 を置いている。これと独自に作成した気管鈎を使用す ることで 106recL, 106tbL の、また右鎖骨下動脈の taping 举上により頚胸境界部の梘野確保が可能となっ た。 32 例中 5 例に反回神経麻痶例が、うち 1 例が西側 反回神経麻瘦を生したがこの原因として神経に近接し た剥離時の電気メスの使用が考えられた。他の合併症 としては術後乳糜胸が2 例にみられたが、いずれい鏡 視下に治療が可能であった。拡大視された画像におい ては脂肪組織と胸管の銀別が困難な場合があり、全体 像もバランスよく見ながらの操作が必要である。「結 論」2D 画像での操作で遠近感がなく合併症の発生を危 惧する意見もあるが、充分に近接拡大梘すること、良 梘野を得ることで安全に行えると考えている。

VS-II-4 上部消化管良性疾患飞対する腹腔鏡下 手術のPitfall

東京慈恵会医科大学外科

○柏木秀幸, 小村伸朗, 渡辺正光, 石棓由朗, 鈴木 裕, 柳澤 暁，青木照明

上部消化管良性疾患に対する腹腔鏡手術として，乙 れまてに食道アカラジアに対する(1)Heller-Dor法( 6 例)，逆流性食道炎行対する(2) Nissen 噴門形成術 (7 例)，十二指腸溃境に対す万(3)選択的近位迷走神経切 離術（13例，乙の内 3 例は小開腹下に Finney 型幽門形 成術を付加) の計 26 例を施行したが，その問題点に関 して報告する。

Pitfall は，手術適応，術式選杓と手術手技に生じ る可能性があるが，開腹下に完成された術式の腹腔鏡 下への移行の過程では、手術手技が問題となる。術中 合併症として、(1)で食道粘膜損傷が2 例, (2)で食道後 壁の筋層損傷が1例に認められた。(1)と(2) 1例で術後 持続的琞下困難が出現し，後者㤌内視鏡的払張老必要 とした。開腹への移行例はなかったが、最大のpitfall は，手術時間の長さであり，特に(3の術式で問題てあ った。しかし、手術手技の工夫に上り，改善が認めら扎 ている。これらの手術に伴5 pitfallと，それに対する 手技の工夫に関し，ビデオにて供覧する予定である。 
VS-II-5 腹腔鏡補助下幽門側胃切除術の検討

帝京大学医学部附属满口病院外科

O丸野 要、直江哲郎、石山純司、島倉和朗、 春日井尚、宮島伸宜、酒井滋、山川達郎

私共が経験した腹胫鏡補助下幽門側胃切除術(LADG) 施行症例は早期胃癌 5 例、過形成ポリープ 1 例、平滑䇨 肉腫 1 例であった。胃癌は 5 例とも術前深達度診断 $\mathrm{m}$ で、 1 例は幽門輪直前の Пc であり、1 例は術前に 2 度 EMR が施行された後別の部位に IIc を諗めた。他の3例は $20 \mathrm{~mm}$ 以上の大きさの病変であった。過形成ポリープは 4 度内視鏡的 polypectomy が施行された後、同部位に再発 を認めた。平滑筇肉腫は径 $5.5 \mathrm{~cm} の \mathrm{SMT} か ゙$ 幽門前庭部 内腔一発育していた。臍下、臍よりやや頭側で左右前腋 窝線上、剣状突起と臍の中央で左右中鎖骨線上の5点に トラカールを挿入した。リンパ節郭清 $D_{1}+$ No.7 施行後 endostapler にて胃を切漏し、ここで左右中鎖骨線上の創 の間で約 $6 \mathrm{~cm}$ 開腹し、腹腔外で十二指腸を切離した。残 胃の前壁を切開し、circular stapler 孝用いて残胃の切離 線上の大弯側端に十二指腸を B-I にて吻合した。平均 手術時間は 4 時間 40 分、平均出血量は $140 \mathrm{ml}$ であった。 7 例とも最長 15 か月の観察で再発を認めていない。深達 度 $\mathrm{m}$ の早期胃癌、EMR や腹腔鏡下胃局所切除術では 根治性が不確実な病変は、LADG の適応と考える。

VS-II-6 胃粘膜下琏蛇に対する鏡視下手術 - 適応亡問题点-

久留米大学第 1 外科

大田準二，山崎国司，山内祥弘，児玉一成，

孝宫士喜久夫、武田仁良，白水和雄

胃粘膜下腫嗐(SMT)はその形態学的特徽により，内視 鏡生検が困難であるばかりでなく，生検材料を用いても 良悪性の術前診断に苦慮することがある. 過去15年間 の悪性例は平滑筋肉腫15例で,リンバ節転移はなく肝 転移1例を認めた. そこで平滑筋肉腫に対しても胃壁全 居切除が有用と考え，術前組織診断が得られなかった最 近の12例(平滑筇肉腫 4 例，平滑筇庫 4 例，神経鞘腫 2 例， 異所性膵 1 例，重複胃 1 列)には腹㚙鏡下胃局所切除術を 施行した，肩所切除の適応は大きさ $5 \mathrm{~cm}$ 以下で，腄悬 を強知せず，胃機能を温存できる症例とした．また，そ の切除線がEG-junctionや幽門輪にかからない例が良 い適応と思われた. 一方，腹腔鏡下局所切除が困難の EG-junction直下径 $2.5 \mathrm{~cm} \sigma S M T$ 例には内視镜下胃内 手術にて核出術を行った. 胃内手術では全局切除は困 難で，浸閏性に増殖することがある悪性例では核出術で は迹残や播種の危険性も考えられる．症例の選択によ り、術前診断が困難な置SMTに対し腹腔鋧下胃局所切除 術は診断と治療を兼ねた有用な方法と考えられた.
VS-II-7

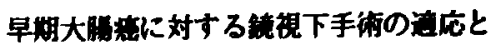
限界

久留米大学 外科

山崎国司、白水和襍、大田望二、山内祥弘、平城 守、 弨内彦之、貝原 浑、賭方 裕

早期大腃虹に对する Transanal Endoscopic

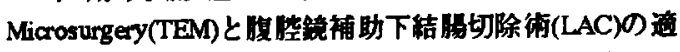
応、手術手技、成綨と限界について这べる。【結果】TEM

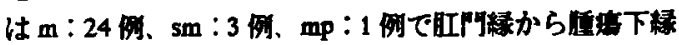

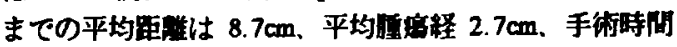

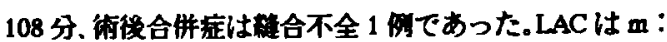
7 何、sm: 10 例に行われ占居部位は S 状結渴と上行結成 が8 例つつと多く、出血量は DO,D1：46ml、D2,D3 :131ml、 手術時間は D0,D1：166 分、D2,D3：283 分、入院期間は D0,D1：11 日，D2,D3：13 日で. 㭪㘼合併应は吻合部狭

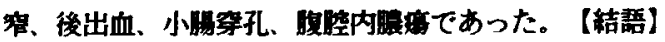
LAC は結Hのあらゆる部位で可能で、恨治㭪を損なうこ

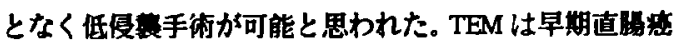
に対して有用であるが、術後病理診で危険因子を有する 場合は硫実なリンバ節部清を伴つ手術が必要と考える。

\section{VS-II-8 腹整鏡下大腸切除術のPitfall \\ 順天堂大学医学部附属浦安病院外科 \\ 福永正氯 八木羲弘 木所昭夫 射場敏明 \\ 杉山和義 福永 哲 百瀨文教 布施暁一 \\ 永仮邦彦 須田 健 太田 辰 工廣紀斗司}

我々は大腸疾患に对し腹胫鏡下大腸切除術 (LAC) 積 柜的に導入してきた。現在までにLACを81例経験し、良 性疾患18例 $22.2 \%$ 、大腸潘は63例77.8\%であった。

開腹移行例は7例8.6\%であるが、最近の店例では全く 経験していない。開腹理由は初期の症例でD3へのリン パ節郭清拡大のため2例、膀胱浸洞に対す万膀朕合併切

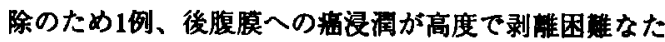
め1例、此血クリッフトラブルによる MA 根部よりの出 血のため1例、高笵囲疮着のため1例、部位診断に問題が あり AW追加切除を必要とした1例であった。

LAC完遂例の主な術後合併症は经合不全2例 $2.7 \%$ (と もにBAR使用例）、創感染 12 例 $16.2 \%$ 、イレウス様症状 5例6.8\%ですべて一過性て、このうち再手術を要した症 例はない。

ポート部再発は末だ取長3年6カ月の経過観察であるが、 開腹移行例で1例 $1.6 \% 、 2$ 年後に再発し癌性腹腅炎、肝 転移を合併し密死した。

これら症例を供覧するとともに、对策についても報告す ろ。 
VS-II-9 腹脭镜卜消化管吻合䋖合手技におおるPitfall 長野市民病院外科

○林賀，宗像康博，兰田第義，西村秀紀，町田恵美

[目的] 镜視下手術の吻合手技は制約が多く難易度の高 い技術と言える，腹腔鏡下の消化管吻合術における手術 手技の工夫とPitfallにつき検討する。［対象］6年間に行っ た腹腔鏡下結腸切除術76例，胃切除術47例，胃空腸吻合 術11例，結腸穿孔部閉鎖術11例，十二指腸穿孔部网鎖術7 例，小腸切除術4例の計156例を対象とした， [万法] 絬 腸切除術で下行䊅腸までは手䋖いかBAL，S 状結腸以下 では Linear stapler (LS)と Circular stapler (CS)を例用した Double stapling method (DS)を基本とした。罢切除術で Lesion lifting法ではLSを，胃内手術ではEndostichによる腔 内繾合を行い，幽門側切除ではLSで胃切除後手䋖い䋖合 を行った，器械吻合は82例（BAL使用7例を含む），手䋖 いは58例，西者の侀用は16例であった。 [絬果]術中の LSによるmisfire，出血は新たなLS処理か止血を行った， 術後䋖合不全は漬菂性大腸炎による穿孔のLS閉鎖の1症例 で発生した $(0.6 \%)$ ．後出血は3例（DS2例，胃空腸吻合 1例）であったが保存的に軽快した．横行結腸切除術の1 例で180度lotationした手䋖い吻合が行われたが問題は㷮かっ た. [結論] 健常部での吻合操作はPitfallを回避すること により開腹手術と同等の安全な手技になりうる.

VS-II-10 鏡視下手術における絵胆管結石切石の pitfall

東京慈惠会医科大学外科，富士市立中央病院外科* 中里雄一, 羽生信羲, 成瀨 勝*, 大平洋一*, 鳥海弥寿雄*, 恩田啓二, 鈴木 裕, 中山一彦, 佐藤䂧一*,山本 尚, 富田春郎, 高楅恒夫*,榴垣芳則，青木照明

[目的]現在，総胆管結石症例に対しても腹拈鏡下手 術が施行されるようになってきているが，ときに給胆 管結石の切石困難やそれによる開腹へのコンバートが ある。そこで今回われわれは絵胆管結石切石における pitfallとその对応の要点につきビデオにて供覧する.

[切石手技にかかわるおもな pitfa l1]1)結石の可動 性の有無.2)術中胆道鏡施行におけるA)トラカールの 挿入位䍡，B）紷胆管の切開位置. 3)紟胆管からの結石 採取におけるA）紷胆管切開時の結石流出および小結 石，B）結石が多数の場合，などのpitfalいがある.

[対策]1)術前胆道造影で結石の可動性を確認，また は結石破砕器具の使用. 2-A,B) 乳頭側よりの給胆管 切開と切開部に近いトラカールが必要. $3 \cdot A, B)$ 切開 時からの切開部の視野の確保と結石回収用袋の利用.

[結語]腹㸃鏡下の総胆管結石切石手技に对しても実 にさまざまなpitfalが゙ありここれを熟知したうえで 適応を決定し，手術を行うことが重要である。
VS-II-11 腹腔鏡下胆道手術の pi t fall -胆管損

傷と出血一

東北学災病院外科

徳村弘寒、梅澤昭子、今岡洋一、大内明夫

山本協二、松代 隆

【目的】腹暌鏡下胆道手術時の胆管損稘と出血を 検討、考察する。【対象】腹腔鏡下胆要摘出術 12 38例を对象。胆管結石で経胆要管的胆道鏡を51例、 胆管切開を62例に追加。【結果】胆管損稘 4 例

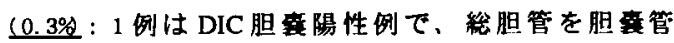
と誤認、術中造影せず完全離断し開腹。1例は急 性胆表炎経過後で龟裂損㑥し檤合。他2例は、高 度慢性胆卷合併と胃全揞術の各 1 例でともに胆 要頝部が総肝管に乗上がった形で复着、術中造影 で気付き開腹せず各々T千ューブと一期的繾合で 対処。出血176例(14.2\%: 出血部位は、胆素床 82例 (太心門脈技2例)，胆衰動脈の胆婁床枝41例、

胆震 16例、胆震動脈 13例、大絧 8例、総胆管8例 などであった。うち開腹移行は2例で、ともに急 性胆霍炎経過後で、大絧剥離部と総胆管切開部か ら出血した。【まとめ】迏管損傷予防には徹底し た䫓部から胆要管への剥雖、特に外側からの剥離 が重要で、発見には術中造影が必須である。出血 は炎症例に多く、手術をさらに困難する。無血野 を心がけ、出血時は冾静・的確な止血操作、特に 圧迫止血が重要である。

vS-11-12 腹腔鏡下胆要摘出術における胆道および 消化管損倡とその対策

関西医科大学第 1 外科

權 雅憲、乾 広幸、今村 敦、上辻章二、上山泰男

[目的］われわれは、従来は開腹を余儀なくされた胆道 や消化管損賃に対しても腹腔鏡下の修復を行っており、 その要因と対策を報告する。［対象と方法］腹腔鏡下胆 霸摘出術を施行した 750 例を対象とした：術前検査とし て稀静脈性胆道造影併用スパイラル CT にて胆道解剖を 立体再構成し、また術中胆管造影を施行した

結果]胆管損偒は 8 例に認められた。術中胆道造影を 施行しなかった 3 例は総胆管を胆复管と誤認した総胆管 䧴断であり、開腹に移行し胆道を再建した。他の 5 例で は術中胆道造影により胆管損傷を確認できたため、腹䶼 鏡下に損偒部を維合閉鎖した。術後胆管狭窄の予防のた め内視鏡的に胆道ドレナーシ tube を㨉入し、入院期間の 短䈹を図った：消化管損偒は胆滖と十二指腸の強固な虑 们剥推に起因し、2例にみられたが、腹腔鏡下に修復し た。また open laparotomyによる小胑損偒を2例認めた が、腹腔鏡下に損偒部を体外に誘導し、縫合閉鎖した。

[結語] 術中胆管造影を楮極的に施行し胆道損倠の有無 を確認することにより、腹腔鏡下の修復が可能であり、 消化管損賃例も腹腔鏡下の修復が可能と考えられた。 
vs-II-13腹腔镜下手沭時の緊急出血に対寸る対処 法およひ防止対策

名古屋市立大学第一外科, 知多匽生病院外科*

今早川哲史，寺西 太米，石原正志*，三宅 孝*，

水野 章*，直辺忠夫

䏹腔鋎下手术の適応は近年爆発的に搪大している， 1990年より開始された腹腔鏡下胆摘出術は現在では 標染術式となっている. 当教室でも $90 \%$ 以上の施設て 標準術式となっているが，集計した全手術症例中開腹 術への移行例が1130例中42例(3.7\%)に詡められた。 そ のうち13例(31.0\%)が血管損倁による緊急出血から止血 困難となり開腹術に移行していた，今回，腹腔鏡下手 術全体におけるpitfallである紫急出血時の対処法とより 安全に手術が可能となる手術法の工夫について以下の4 点を供覧する.【1】胆事摘出術時の右肝動脈より分枝 した胆串動脈のpunch out出血時の対処法, 眼器の革引 压迫，器具の使用法.【2】急性虫垂炎手術時の虫垂動 眽よりの緊急出血に対する止血法と出血を防止する器 具の選択.【3】へルニア修復術時の穿通枝およひ腹壁 側からの出血に対する止血操作.【4】結腸整手術時に 二つのCCDカメラを使用するdual vision surgeryにより， 䁍器背側の状態を確認し正確な手術操作による出血の 防止．紫急出血時における助手との鉗子協調操作によ る確実な出血点の把握と的確なuraction操作と止血法.

VS-II-14肝疾患に対する腹腔鏡下手術の適応桩大 と問題点

東邦大学第 2 外科

○金子弘真、高机純人、光丸哲吉、柴 忠明

腹腔鏡下手術の肝疾患に对寸る適応拡大のための工夫 と問題点について供覧する。腹腔鏡下肝切除：適応は 腫瘍が肝卜区域の表面や辺縁あるいは外側区域に局在 する、腫瘍径 $5 \mathrm{~cm}$ 以下とした。視野展開にはCO2塞栓 の危険性からつり上げ法を用い、肝実質切隻にはマイ ク口波凝固装置と超音波吸引装置の併用が有効で、肝 外側区域切除例の太い脈管は腹腔鏡用自動䄼合器によ り安全に切離できた。対象症例は原発性肝癌 7 例、転 移性肝癌 3 例、肝良性腫瘍 5 例の計 15 例で開腹移行 例は 1 例で他全例は安全に施行でき経過も良好であっ た。マイクロ波凝固療泣 $(\mathrm{MCT})$ ：肝予備能不良な原発 性肝癌 6 例に胸、腹腔鏡下MCTを施行、術後経過は 良好であったが、腫瘍の局在によっては電極刺入部位 が制限された。肝胞開悹術：7例に施行し極めて低 侵襲であった。アルゴンビームは蒌残策胞上皮の焼却 に有効であったが胞の大きさや部位によっては完全 焼却が困難である。肝疾患に対しても腹臆鏡下手術は 症例を旅選し問題点を充分に把握することにより侵軗 の少ない安全な術式になると考えている。
VS-III-1 肺腫瑒に对する鏡視下手術の問題点と工夫 神戸大学医学部第…外科、灘金沢病院外科 1 、協 和病院外科 2 、新日鐵広畑病院外科 3

山本英博，岡田昌義，真庭謙昌，高田昌彦、松阊

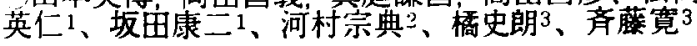

肺腫湯に対する鏡視下手術の問題点として腫痬 の存在する部位によりアプローチの方法を考慮す る事が必要である。

方法；既に皮虔切開がある場合はその切開を用い 通常、基本的に第5肋間中腋下線上に $18 \mathrm{~mm}$ の皮 虚切開を加える。演者らは独自に開発した螺旋状 に屈曲したスコープガイドの中に、デジタル式軟 性気管支視鏡の本体を通し、胸腔内に挿入する。 ついで、肺を把持し、胸腔内の観察を行う。さら に、肺の切除は、把持鉗子と同様に自動栈合器を 挿入しstapling を行う。

結果と考察：これら3つの手術器具は、スコープ ガイドにより、皮切開部分で干渉せず、各々の 操作性が保たれ、手術が可能となった。腫瘍の存 在する部位に関わらず本術式は一カ所の小切開で 腫瘍の切除が可能であり、2〜4カ所のポートを必 要とする従来の方法に対比し本法は低侵䀜である といえる。

\section{vS-III-2 肺漼に対する胸整鏡リンパ節郭清の限 \\ 界と工夫 \\ 山口大学第 1 外科 \\ ○杉 和郎, 藤田信弘, 上田和弘, 縄田浩一, 金田好和, 江里健輔}

【目的】胸些鏡リンパ節部清の現状を検討し、より確 実な部清への工夫を模索する事を目的とした。

【对象と方法】胸偾鏡りンパ節郭清が施行された30例 における部清筑围、リンパ節個数を開胸によるリンパ 節部清(65例)と比较した。【桔果】胸璄鏡りンパ節郭 清は右徙隔で仕開胸と寀色なかった。しかし右下葉切 除における\#12u部清では開胸による部清に劣っていた (0.8 vs. 2.1$)$ 。左上縦隔(\#1-3)部清は胸整鏡では行 之なかった。動脈管索を切離する事により、開胸に劣 らず非清を施行できたか、\#4郭清は開胸に比べやや 秀っていた。井7部清( 1.5 vs. 3.0 )、左肺門の郭清( 1.3 vs. 3.3)、およひ左下葉切除における\#12u部清( 0.8 vs. 2.3)は開胸による郭清に劣っていた。

【考察】胸腔鏡リンパ節郭清はいくつかの領域で開胸

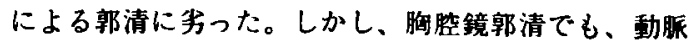
管の切離に加えて大動脈脱伝、肺動脈テーピンクによ る不意の出血への対処などの工夫により、郭清の做底 が可能と考えた。 
Vs-III-3 肺稆に対するVideo-assisted lobectomy困難例に対する工夫

北海道大学第二外科1)，南一条病院胸腔鏡センター2) ○森川 利昭 ${ }^{1)}$ ，高橋 利幸 ${ }^{1)}$ ，奥芝 俊一1)，加

藤 紘之1)，竹内 惠理(保1)，2），大淵 俊朗1)，2）

【目的】Video-assisted lobectomy侵蛀度が低く， 安全性にも優れた手術法で、肺癌症例もその適応と考 えられる。しかし，開胸手術より操作性が不良な症例 もあり，その問題点と工夫点を明らかにすることを目 的とした。【症例と方法】我々の連䌇100例の肺癌症 例に対するVideo-assisted lobectomyの経験から， 困難な因子である1)肺之胸膜の痹着2)不全分葉3)肺門 リンパ節腫張をとりあげ手技上の工夫点を検討した。

【結果と結論】1)癁着剥離は，胸腔鏡の適切な位圈か らの良好な視野確保により開胸術と同様か，より良好 な操作が行える2)不全分莱症例では，初めに血管や気 管支を処理し，最後に葉間形成を行うことにより安全 に処理できる3)反応性の肺門リンパ節腫張により血管, 特に肺動脈周囲の剥䧳は困難となるが，必要な大きさ の小開胸創を第4肋間前腋窝線上に置くと，肺動脈が 直梘でき, 通常の手術器具が使用できるので直視下の 操作も可能である.これらの工夫により手技的な理由 から開胸術へコンバートした症例はみられなかった。

VS-III-4 術前確定診断のつかない肺内末梢小腫 瘤性病变に対する胸腔镜下手術の問題点とその工夫

国立札幌病院北海道がんセンター外科

○近藤啓史、佐ヶ木迪郎、内藤春彦、高橋宏明、有倉 潤、高岡正実

【目的】我々は鏡視下肺部分切除（肺生検）を術前確 定診断のつかないゅ $2 \mathrm{~cm}$ 以下の肺内末梢腫瘤病変に対 し行ない、手術術式を決定するのに応用している。今 回はこれらの問題点と工夫について検討したので報告 する。【対象】97年 4 月までに対象となった症例は74 例89病変である。【結果】病理診断の結果、肺内リン 八゙節 (5例 5 病変)、炎症性 (同 $10 、 13)$ 、結核腫 $(9,10)$ 、

過誤腫 (7、7)、肺転移 $(18 、 29)$ 、肺癌 $(24 、 24)$ 、他 1 例であ った。その内肺癌14例は引き続き開胸肺枼切除、4例 はVATS肺葉切除を行った。【考案・結論】(1)羱視下肺

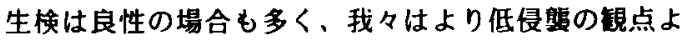
り手術器具の開発を行い 2 ボートにて手術(30例)を 行ってその有用性を認めた。(2)経済性の面より新しく 考案した結紮䋖合器具により最後の1 fireを節約する ことが可能になった。(3直径1cm 以下で梁部に存在す る腫瘤の肺生検は困難を有し、術前に肺内マーキング を行うことの有用性を認めた。しかし脳内空気塞栓の 重篤な合併症もあることに注意を唤起する。
VS-III-5 肺小腫在に対するCT下針留置による胸 腔鏡下切除術

埼玉医科大学第 1 外科

○金子公一、森田理一郎、苩 理猎、美港岛卓哉、 小川展二、小澤修太郎、尾本良三

【はじめに】術中の蚛診が不可能と思われる肺小腫覃 を短時間で確実に切除するために街前にCTガイド下に フック針を刺入し、針を指標に胸腔鏡下に肺部分切除 を施行した。【対象・方法】1996年11月から97年3月ま での5か月間で7例に施行した。年龄は50〜76(平均 63.3) 藏、男5 : 女2であった。手術直前にCT室にてCTカイイト 下に腫瘤に接してフック針を刺入してから手術室に入

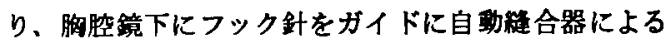
肺部分切除を行って腫海を切除した。【結果】摘出さ

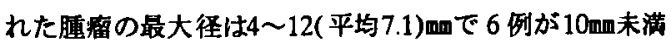
であった。最終診断は腺癌 2 、結核結節 2 、胸膜下リ ンバ節 2、クリプトコッカス症 1 であった。フック針 刺入による手術合併症はなく、胸腔鏡挿入時に1例でフ ック針が脱落していたが、肺表面の針刺入刢が確認さ れ自動縫合器にて腫留は切除しえた。【まとめ】CT下 針留置による胸腔鏡下腫湭切除術は肺表面から深い小 腫㾌でトロカー孔からの触診による位置碓認が不可能 と考えられる場合には有用な方法と思われた。

\section{VS-III-6 肺腫㻛に対する彰断的胸暌鏿手術の問}

題点と工夫

藤枝市立総合病院心成呼吸器外科 ${ }^{1}$ 、溙原総合病院 呼吸器外科 ${ }^{2}$ 、焼津市立総合病院外科 ${ }^{3}$

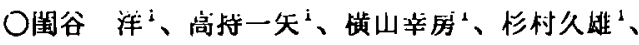
大井 諭 ${ }^{2} 、$ 小林 亮 $^{3}$

【はじめに】末確診の肺腫瘍に対する診断的胸哚鏡手 術は比較的一般化しているが適応や手技等には関して は問題点もある。【対像と方法】67例の末梢型肺腫 㻛に対して胸燃鏡下生検を行い術中病理部断により最 終術式を決定したが、操作手技等いくつかの問起点に ついて検討した。【結果】良性病变は35例で全例胸 腔鏡下肺部分切除を行い、墨性病変 32 例中 29 例か 原発性肺癌で 16 例は開胸根治術、13例は縮小手術 としての胸胿鏡手術を施行した。【問題点と工夫】(1) 腫瘦および病変の確認・切除標本の摘出のため 39 例 に小開胸を追加した。(2)術中腫湯確認が困難な症例は CT透視下にポイントマーカーを挿入し指標とした。

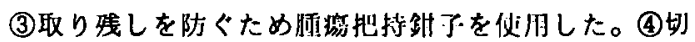
除断端の出血や肺拨対策として自動槰合器の選択・用

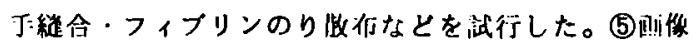

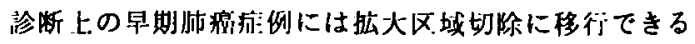

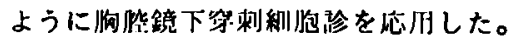


VS-III-7 肺悪性腫瘏に対寸る胸腔鏡手術の工夫 福岡大学第二外科

岩崎昭鲁，吉永康照，川原克信，白石武史，岡林宽， 白日高歩

教室ではこれ迄に380例の胸胵鏡下手術実施した。 うち原発性肺癌は32例, 転移性肺癌は25例であっ た。原発性肺癌については当初右側末梢発生でI期の 扁平上皮㹸を対象としたが，左侧であっても mini 開胸部の有効な利用、ハーモニックスカルベルの利用 等により，かなりの垶清が可能との判断を持つに至っ た。従って今後bulkyな繸隔リンパ性転移以外の非小 細胞性肺癌の多くを対象としてゅく方針である。 video供筧の症例：72才の男性。高度の肺気腫を合併 した症例である。肺癌に対して低肺機能を理由に他施 設で肺部分切除を施行されたが，切除断端再発を認め 再手術の必要性に迫られた（1秒量 $450 \mathrm{ml}$ )。我々の 施設で右肺の胸臆鏡下volume reduction (VRS) と左 肺の開胸下上区切を実施し退院した。他1例で我々が 通常実施しているVATS肺葉切除の方法を供覧する （70才男性， stageI，右上葉切除）。

VS-III-8 胸腔鏡下肺癌手術の問題点と工夫

東海大学医学部外科学教室呼吸器外科 0岩崎正之、朴在善、米谷文雄、西海昇、 加賀基知三、鶴見豊彦、井上宏司

【目的】術前診断Stage I, II肺癌症例で、胸腔内人 のaccess法が異なるだけで、従来の方法と同様に胸腔 内操作が可能である。われわれは、二空法手術開発か ら4年目にあたり、開胸手技の工夫に加え手術器具に も工夫を加え、胸腔鏡下肺癌手術をさらに容易に的 2 ー 3 時間で終了出来るようにしている。標隼開胸手術 症例 50 例と胸腔鏡下手術症例 50 例の成績と問題点 について比較検討した。【結果】手術時間は、檩準開 胸手術例 3 時間 12 分、胸腔鏡下手術例 2 時間 53 分c 郭清縦隔リンパ節数は、標準開胸手術例 2 7、2個、 胸腔鏡下手術例 $23 、 4$ 個であった。経過観察期間最 長 4 年である。3年生存率は、標隼開胸手術例 77 、 $3 \% 、$ 胸腔鏡下手術例 $97 、 5 \%$ われわれの胸璄鏡下肺癌手術は、標準開胸の皮居切開 を胸腔鏡の併用で次第に縮小して来た結果、現在の二 空法になった。従って、胸胫鏡下手術で標淮開胸に近 づけていった場合とでは、コンセプトが異なる。Stag e I，II肺㿋症例では、手術手技の酱䰻によって標準開 胸と同等の手術が可能である。

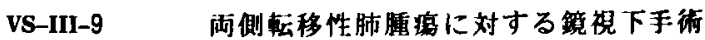
の工夫一朐空鏡併用胸骨正中切開法一

京都府立医科大学第 2 外科

○戸田省吾、小野面、井伊洋弘、西村元去、川田雅 俊、小棉帝生、岩畸靖、和田行雄、岡隆宏

【目的】両側の肺転移に対する各開胸法の欠点を盏う 方法として、胸腔鏡を併用した胸骨正中切開法を施行 し良好な結果を得た。

【対象と方法】同法を施行した14例。原発紧は骨・软

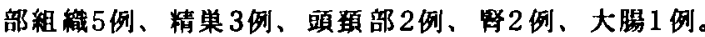
胸骨正中切開で胸腔内を観祭したのち、腫㾇摘出に最 適な左右側胸部より順次购腔籍を捙入。背側の腫痛は、 手を開胸創から括入し、モニターで確認しつつ炀除。

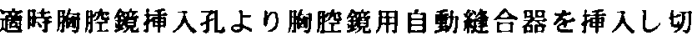
除。胸腔鏡择入孔は術後ドレーン择入れに使用。

【結果】腫澹の個数は5個から30個までであったが、 全例で背側の腫㾕も容易に摘出できた。術後の呼吸機

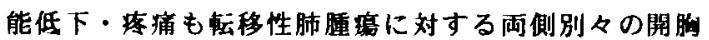
法に比し轱微であった。

【考察】胸胃正中切開のみでは処理しにくい背側の腫 瘤も、胸腔鏡で正面視することにより容易に処理でき た。両側別々の開胸に比し手術時間も短く、術後の呼 吸抑制や疼痛も少なく有用な方法であった。

VS-III-10 胸腔鏡下手術新ディスプレイシステム 東京医科大学外科第一楛座

○酒井治正，田口雅彦，中嶋 隆，古川欣也， 奥仲哲弥，斎藤 誠，中村治彦，河手典彦， 小中千守，加藤治文

〔目的〕胸腔鏡下手術(VATS)の発展、普及には目を見 張るものがあるが、ベッドサイドのモ二ターを見なが ら手術を行うというスタイルは開発初期より変わって いない。VATS の難易性は、この根本的なディスプレ 一の仕方にあるといっても過言ではない。VATSをよ り容易かつ安全にするため、新たな視点に立ったティィ スプレーシステムを開発した。〔方法了薄い液晶モ二 ターを、専用アームで体表上約 $10 \mathrm{~cm}$ の術野直上に固 定する。この際モニター画像の位置及び大きさと解剖 学的位置関係とができる限り同一になるように調節す る。これによりあたかも体表に空があるかの様に内部 を観察することか可能となる。【結果〕本システムに より、鈷子等の動きは、従来の開胸手術を行うがごと く認知された。また新たに開発した専用の手術器具を 用いることにより、従来の開胸術を行うのに近い感覚 でVATS を行うことができた。〔まとめ〕液晶モ二タ 一を用いた本システムは、VATS をより容易かつ安全 に施行する、全く新しい方法となる可能性を有する。 
VS-IIL-11 ハーモニック・スカルペル（HS）を用

いた胸腔鏡下肺部分切除

済生会神奈川県病院 呼吸器外科

青木 腪浩、加勢田 静

我々呼吸器外科医にとって転移性肺腫場に対する手 術、肺生検、肺囊胞に対する手術と、肺を部分切除す る機会は比較的多い。しかし通常の stapler を使用 する方法では、繾合部分で肺を繾い緍めてしまい、 残った肺の膨張を妨げる結果となる。

一方、切除部が面になる方法は肺を切除すると残っ た肺の膨張が生理的に維持されるが、切除部位の劦気 漏れと、出血のため困難であった。

近年 (HS) が腹部外科領域で使用されその止血効果 の有用性が言われている。これは組織をはさみながら 超音波振動によって組織を凝固させるものである。今 回胸䏶鏡下で、(HS)を使用し、肺部分切除を行った。

肺を面で切除し、残存肺の広がりを維持し、切離断 端は空気漏れの残る部分を縫合し、フィブリン糊 and/or GRFグルーと、デキソンメッシュで被覆し終 了した。この様に肺部分切除を行うにあたって特に重 篤な空気漏れ、出血は無い。

今回この手技を供覧する。

VS-III-12肺腫瘍に対する胸腔鏡下手術の臨床的 検討

日本大学医学部第二外科

○村松 高、大森一光、北村一雄、並木義夫、長坂不 二夫、古賀 守、四万村二恵、新野哲也、賴在 幸 安

【目的】近年、胸谐鏡下手術は自然気胸などのブラ切 除の治療に使用されるばかりか、肺堹懪に対しても使 用されてきている。そこで今回我々が経験した肺腯場 に対する脑㓐鏡下手術につて臨床的問題点と工夫を中 心に検討したので報告する。

【対象】1992 年3月から1996 年12月末まで に当施設挹よび関連施設にて胸些鏡を使用した症例は 273例であった。このうち、肺腫捠に对して胸脄鏡を 使用した症例は 31 例である。原薙患は転移性肺腫富 19例、肺良性脏瘦8例、肺㾇4例であった。性は男性 2 4例、女性7例で、年龄は 29 嵗から 75 葴（平均53.1 盛)であった。これらの症例に対して肺部分切除26例、 喢境核出術+肺綎合3例、肺葉切除 2 例を行った。

【結果】これらの症例の内、肺腫場に対する胸䏶鏡下 肺部分切除術、属境核出術十肺縫合、肺葉切除術につ いて問題点と有用性についてビデオにて供覧する。

\author{
VS-IV-1 当科における下肢静脈海の治療方針 \\ 大阪大学第 2 外科

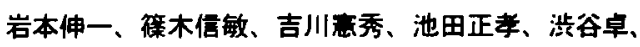 \\ 川崎富夫、左近贤人、門田守人
}

[目的]伏在系下肢静脈每に対する高位結慗術併用硬化 療法の際に、高位結惄術以下の部位に対して石化療法で 対処するか、静脈秸等で対処するかは施没每に相連があ る。今回、最近当科で行っている濝部限局的ストリッピ ングを併施した高位結禁術及び二期的硬化淹法の方法お よひ成維について供監する。(方法高位結等術阱用硬化 痛法施行した68例102肢(A群) と㮏部限局的ストリッピ ングを併施した高位結紮術併用硬化療法施行した65例 90 肢(B群)について1，棦脈桔禁䓢所数 2，総硬化剂使用

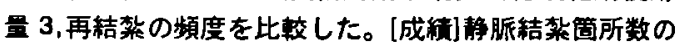

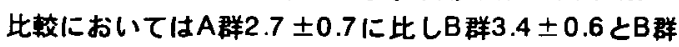
が有意に多かったか、、粉硬化剂(Naコンクライト)使用 量はA群9.2 $\pm 6.9 \mathrm{ml}$ に比しB群5.8 $\pm 5.8 \mathrm{ml}$ とA群が有 意に多かった。再桔焚術を要した症例はA群16例21肢 に対しB群 1 肢であった。さらに二期的(街後 1 力月後) に硬化療法施行した症例は硬化剂使用量 $5.5 \pm 6.0 \mathrm{ml}$ と 更に少なかった。APG(air plethysmography)による 静脈機能評価は両群間に差はなかった。[結論]滕部限局 的ストリッピンクをを併施した高位結等術及ひ二期的不化 瘾去は再発防、硬化㓮减少に有効であると考えられた。

vS-IV-2 一般病院における下肢静脈痹治療のと りくみ公開講來と日㷌り手術センターを利用した 選択的ストリッピングを中心とした治療への転換

湘南鎌倉総合病院外科

○梗口倫代、渡部和巨、篗崎伸明

〔目的〕当院で下肢静脈瘤に対して選択的ストリッピ ングを施行し始めてからの治療状況をまとめた。

〔方法〕 $\mathrm{H} 8$ 年 12 月 $-\mathrm{H} 9$ 年 3 月に静脈瘤外来を受 診した 53 人について reviewした。

[成精] 53 人中硬化療法単独を 6 人、手術を 27 人 （硬化療法併用を含む）に施行した。手術内容は選択 的ストリッピング+瘤切除 19 人、瘤切除 5 人、選択 的ストリッピング 2 人、高位結紫術+瘤切除 1 人、手 術時間は平均 59 分であった。1ヶ月後の満足度は手 街施行例 27 人中全員が大変満足又心満足と回答した。 〔結論〕地域の公開講座での啓蒙、日㷌り手術センタ 一を利用しての入院当日の瘤造影と手術、一泊入院な どをとり入れて、選択的ストリッピングを中心とした 治療方針に変更したとてろ患者数は増加し、短期成績 ではあるが良好な結果を得た。専門病院以外では敬遠 されがちな疾患であるか、一般病院でも充分対応可能 であると判断した。 